\title{
Technical and economic analysis of using biomass energy
}

\author{
Małgorzata Piaskowska-Silarska ${ }^{1, *}$, Stanisław Gumuła ${ }^{2}$, Krzysztof Pytel $^{1}$, Piotr Migo ${ }^{1}$ \\ ${ }^{1}$ The Pedagogical University, Faculty of Mathematics, Physics and Technical Science, ul. \\ Podchorążych 2, 30-084 Kraków, Poland \\ ${ }^{2}$ AGH University of Science and Technology, Faculty of Energy and Fuels, al. Mickiewicza 30, 30-059 \\ Krakow, Poland
}

\begin{abstract}
In the first part of the article were presented the technical possibilities of obtaining solid biomass, biogas, landfill gas, a biogas from wastewater treatment plants, bioethanol and biodiesel. Then processes was described, allowing use of energy from biomass. As first was discussed the incineration which includes drying and degassing of the wood materials, wood gas burning at $1200^{\circ} \mathrm{C}$, post-combustion gas and heat transfer in the heat exchanger. Then had been described gasification, or thermochemical conversion process, occurring at high temperature. It is two-stage process. In the first chamber at deficiency of air and at relatively low temperatures $\left(450-800^{\circ} \mathrm{C}\right)$, the fuel is being degasified, resulting in creating combustible gas and a mineral residue (charcoal). In the second stage, secondary combustion chamber and at a temperature of about $1000-1200^{\circ} \mathrm{C}$ and in the presence of excess of oxygen resultant gas is burned. A further process is pyrolysis. It consists of the steps of drying fuel to a moisture level below $10 \%$, milling the biomass into very small particles, the pyrolysis reaction, separation of solid products, cooling and collecting bio-oil. Then discusses co-generation, which is combined production of heat and electricity. In this situation where the biomass contains too much water it can be used for energy purposes through biochemical processes. The alcoholic fermentation results in decomposition of carbohydrates taking place under anaerobic conditions, and the product is bioethanol. Another biochemical process used for the production of liquid biofuels is esterification of vegetable oils. Methane fermentation in turn causes a decomposition of macromolecular organic substances with limited oxygen available. As a result, we obtain alcohols, lower organic acids, methane, carbon dioxide and water. There was analysis of economic increasing of solid biomass energy, biogas and liquid biofuels in the following article.
\end{abstract}

\section{Introduction}

The use of biomass as central heating and domestic hot water preparation is nothing innovative, but only return to thermal energy generation by man for thousands of years. Using wood for heating in Europe and other parts of the world was very popular and widely used.

\footnotetext{
*Corresponding author: mpiasko@up.krakow.pl
} 
It was not until the discovery of fossil fuels, greatly reduced the use of biomass. The main reason for this was significantly greater calorific value of fossil fuels, and better technical possibilities of their storage and transportation. If the present resources of conventional fossil fuels, ie. Coal, oil or gas did not exhaust itself at such a fast pace, and their price on the world market did not grow as dynamic and interest in biomass as an energy source would probably be marginal.

\section{The analysis of technical possibilities to use a biomass as Energy}

Analyzing the possibility of obtaining biomass energy in Poland, one have to start with a discussion of its resources. Considering the technical and financial costs of $739 \mathrm{TWh}$ theoretical potential of biomass we get real economic potential, of more than four times smaller. If we compare it with the demand for energy, it turns out that it is more than four times smaller (Fig. 1).

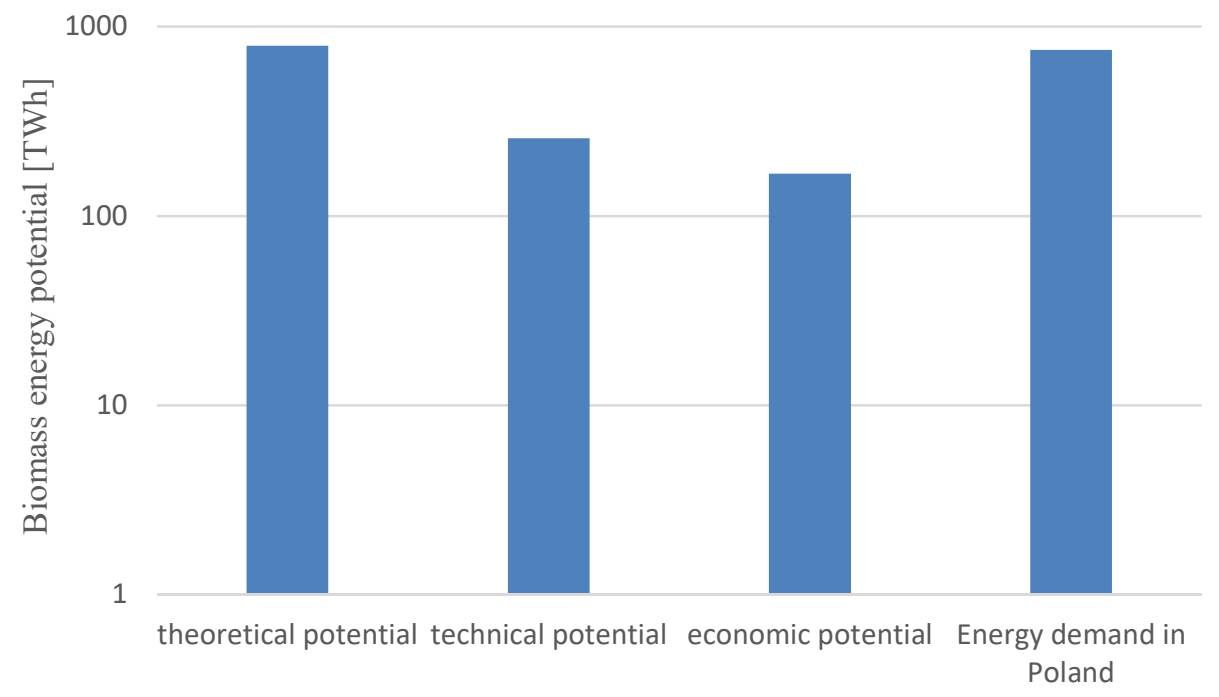

Fig. 1. Biomass resources in Poland [14].

However, as can be seen in Fig. 2, the proportion of energy from biomass in households per 1 inhabitant is comparable with conventional energy sources such as natural gas and electricity. 


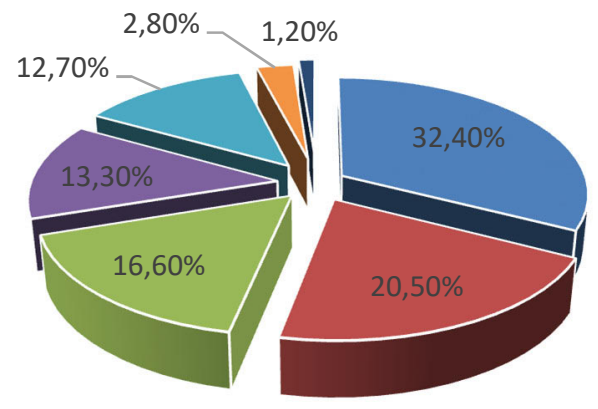

- coal

- system heat

- natural gas

- solid biomass

- electricity power

- LPG

- other sources of energy

Fig. 2. Structure of energy consumption in households calculated per 1 inhabitant by specific energy sources in 2014. [13].

Comparing while obtaining energy from biomass and other renewable energy sources (Fig. $3)$, it is clear that it represents $88 \%$.

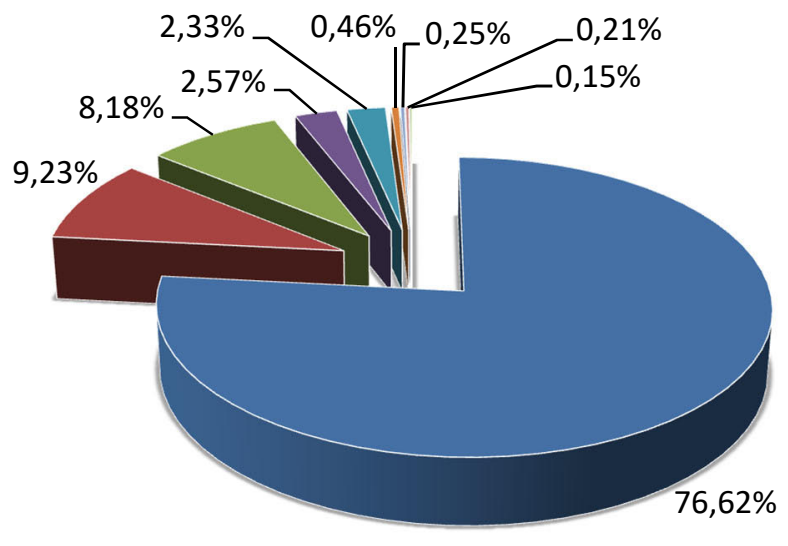

\author{
n solid biofuels \\ - liquid biofuels \\ wind energy \\ - biogas \\ water energy \\ - municipal waste \\ geothermal energy \\ n solar energy \\ heat pump
}

Fig. 3. Obtaining energy from renewable sources by media in 2014 in Poland [13].

If we trace the share of solid biofuels, liquid biofuels and biogas (Fig. 4) in obtaining energy, in 2010-2014, we will notice a continuous decrease in the use of solid biofuels. There is a growing of liquid fuels (except for the year 2011, when the trend was reversed) and biogas. 


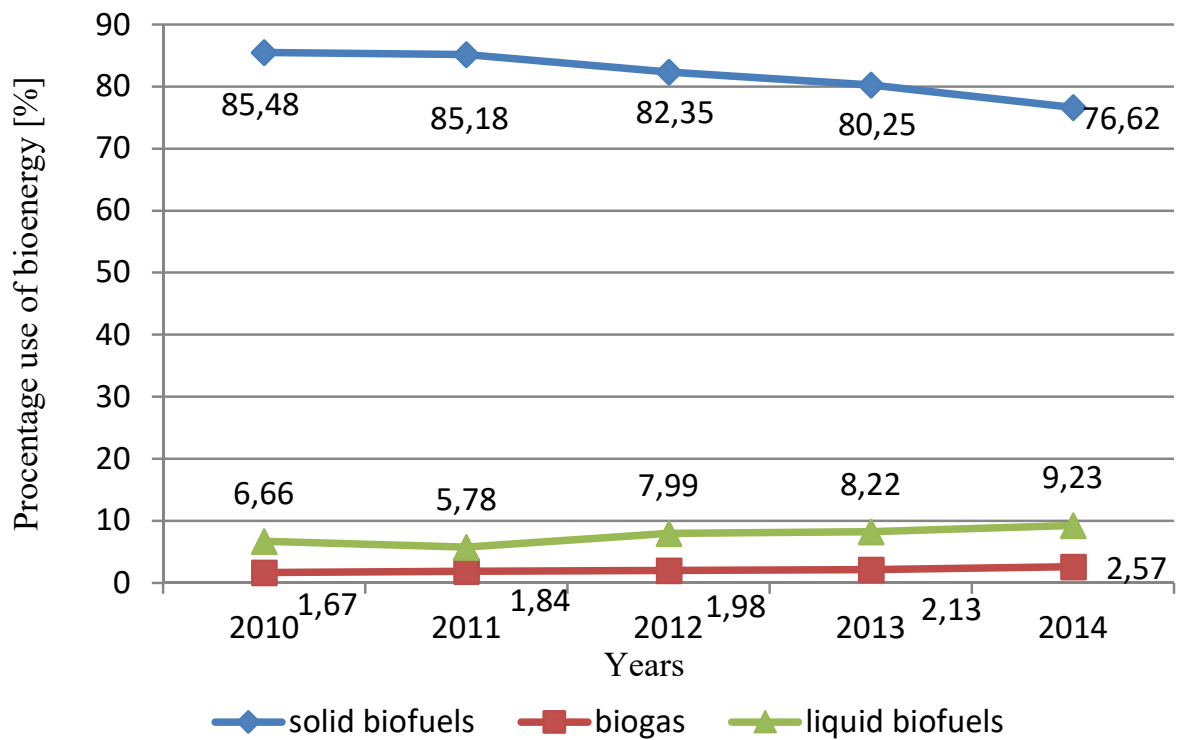

Fig. 4. The share of solid biofuels, liquid biofuels and biogas in obtaining energy in 2010-2014 [13] In the next graph one can see how was as obtaining biogas in 2010-2014, depending on its place of production. More and more we gain biogas from wastewater treatment plants and other biogases. The share of landfill gas in obtaining energy is getting smaller (except the year 2011 when there was a temporary increase in its use) $[1-4,6,10,16]$.

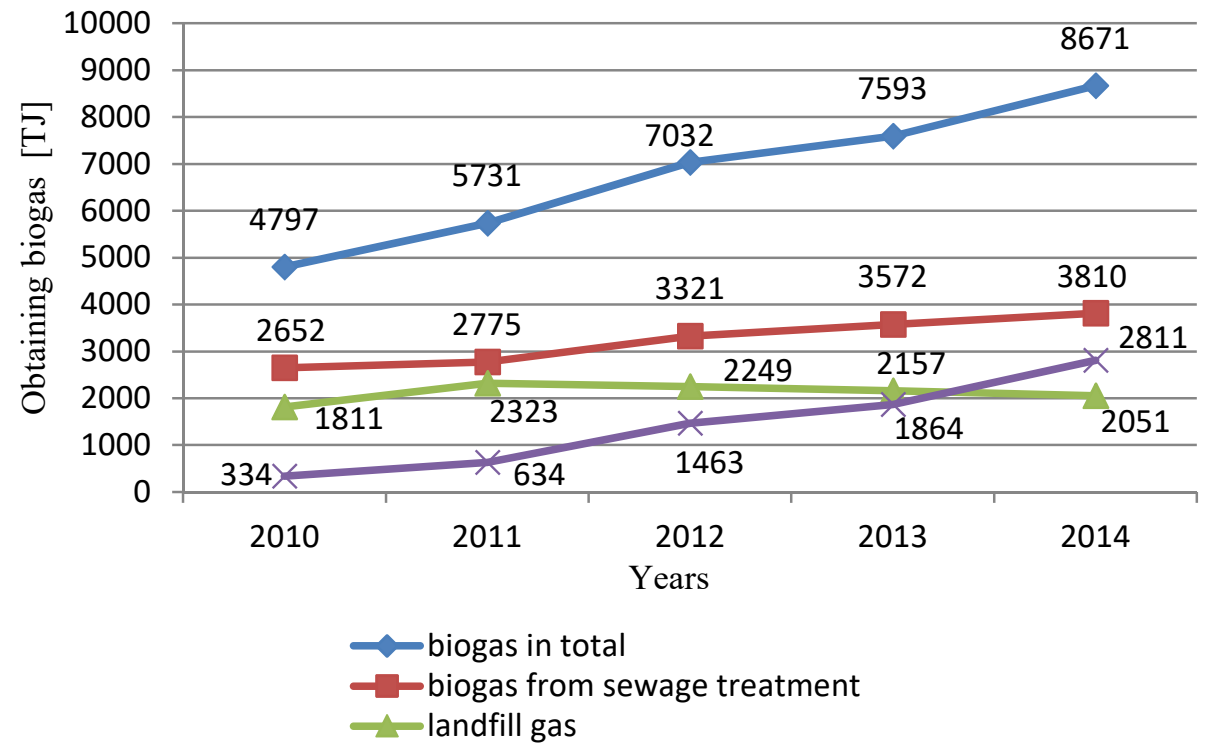

Fig. 5. Obtaining biogas in 2010-2014 [13]. 


\section{Technology of obtaining energy from biomass}

\subsection{Combustion}

Combustion is the most common and simplest means of obtaining heat and electricity from biomass. Combustion efficiency of wood meet environmental protection standards, should be performed in three phases:

- drying and degassing the wood material, which results in a timber gas

- burning wood gas at a temperature of $1200^{\circ} \mathrm{C}$,

- afterburning gas and the heat transfer in the heat exchanger.

In addition, high temperature, appropriately long burning time, with good access of oxygen can reduce emissions of carbon monoxide, hydrocarbons and polyaromatic hydrocarbons. In addition to efficient combustion of biomass, which is also reflected in the ecology, it is worth using boilers with increased heat transfer surface.

The efficiency of the combustion process affects the amount of supplied air. In modern boilers for combustion is supplied so called primary and secondary air. The primary air mixed with the fuel is used in the gasification and burning charcoal. The secondary air is used for combustion of volatiles.

Boilers for combustion of biomass have the power of several $\mathrm{kW}$ to several hundred MW. Typical furnace is composed with a combustion chamber lined with usually high-temperature resistant ceramic material and the grid. We can divide grates fixed, mechanical grates flat and stepped. Boilers with grates fixed or mechanical horizontal used to fuel combustiondried. While the boilers equipped with moving grates stepped are used for wet fuels. This solution allows the evaporation of water from the fuel in the first phase and then completely burned as you move into the hearth. It is also used in boilers with fluidized bed furnace, which enables efficient combustion of biofuels poor quality while maintaining low emissions. Boilers for combustion of biomass can be equipped with automatic control and forced supply air [5, 7-9, 11, 12, 15, 17, 23, 24, 27, 32].

\subsection{Gasification}

Gasification is a thermochemical conversion process, occurring at high temperature, where the product is a gas:

- combusted to provide thermal energy.

- used in microwave, gas turbines, used for the production of electricity and machines, performing mechanical work.

The process of gasification of solid fuels takes place in two stages. In the first chamber at a shortage of air and relatively low temperatures (450-800C), the fuel is degasified, resulting in a combustible gas and a mineral residue (charcoal). In the second stage, the secondary combustion chamber at a temperature of about 1000-1200C, and in the presence of excess oxygen is burned of resultant gas.

An advantage of gasification is efficiency at high-level $35 \%$ and in the near future even 45 $50 \%$, while the efficiency of small and medium-sized equipment used for combustion is 15 $20 \%[11,12,25,26,28,29]$.

\subsection{Pyrolysis}

The product of pyrolysis is a liquid bio-oil or bio-called pyrolysis oil, which is a mixture of oxygenated hydrocarbons. The pyrolysis process includes the following stages:

- fuel drying to a moisture level below $10 \%$, 
- milling the biomass into very small particles in order to provide a quick reaction, and

- pyrolysis reaction,

- separation of solid products,

- cooling and collecting bio-oil.

During pyrolysis the biomass is converted thermally in the absence of oxygen. Depending on the course of the pyrolysis process can be distinguished: conventional rapid and instant.

Fast pyrolysis is characterized in that the small particles of biomass, low humidity, are very rapidly heated to a temperature of $450-5500 \mathrm{C}$, thereby forming pyrolity oil (75\%), charcoal $(12 \%)$ and a mixture of combustible gas $(13 \%)$. Pyrolity oil can be used directly as a fuel or used to produce other substances. The main advantage is the ease of storage and transport. Charcoal and a mixture of combustible gases are burned directly, thus providing heat for the process of pyrolysis $[11,12,19,21,30]$.

\subsection{Combined Heat and Power}

Combined Heat and Power allows the combined production of heat and electricity. Thus allows to reduce fuel consumption and reduce emissions. In associated systems utilization rate of the chemical energy of the fuel is as high as $80-90 \%$, thanks to the recovery of highquality heat from the exhaust.

In the case of acquisition of straw as fuel, you can use a system of CHP: CHP plant from a steam turbine or steam engine (with lower values of electrical power). It would consist from a steam boiler with heating steam, steam turbine and generator of electricity. Shredded fuel would be given to the first lock fire, and then feeding screw stepped grate, which naturally occur combustion. A pair formed in the boiler passed to a steam turbine [11, 12, 22].

\subsection{Biochemical processes}

In a situation where the biomass contains too much water it can be used for energy purposes thanks to biochemical processes. Alcoholic fermentation causes the decay of carbohydrates, taking place under anaerobic conditions after adding yeast to the raw materials such as corn, wheat, grapes, sugar beets. Fermentation product is bioethanol. Another biochemical process used for the production of liquid biofuels is the esterification of oil. It allows you to be methyl esters: biodiesel, liquid biofuels from vegetable oils containing methanol (eg. rapeseed, soybean).Methane fermentation causes the degradation of macromolecular organic substances with limited oxygen. As a result, we obtain alcohols, lower organic acids, as well as methane, carbon dioxide and water [11, 12, 20,31].

\section{Economic analysis of biomass energy generation in Poland}

The economic analysis was carried out for three types of biomass boilers, ie. For combustion fragmented wood, pellets and wood chips. For the purpose of calculating annual need for thermal energy was assumed the level $180 \mathrm{GJ}$ or $50000 \mathrm{kWh}$.

Fuel consumption for a given type of boiler was performed on the basis of the following formula:

where:

$$
\mathrm{B}=3600 \times \mathrm{Q} / \mathrm{W}_{\mathrm{d}} \times \eta \times(\rho)
$$

$\mathrm{Q}$ - the need for heating demand $[\mathrm{kWh} /$ year $]$

$\mathrm{W}_{\mathrm{d}}$ - the calorific value of fuel $-[\mathrm{kJ} / \mathrm{kg}],\left[\mathrm{kJ} / \mathrm{m}^{2}\right]$

$\eta$ - the boiler efficiency

$\rho-$ fuel density $\left[\mathrm{kg} / \mathrm{dm}^{3}\right]$ 
Calorific value and efficiency of the boilers are presented below.

Table 1. Calorific value and fuel efficiency of boilers for domestic purpose.

\begin{tabular}{|l|c|c|c|}
\hline Fuel Type & Fragmented wood & Pellet & Wood chips \\
\hline $\begin{array}{l}\text { The calorific value } \\
\text { [kJ/kg] }\end{array}$ & 14000 & 19000 & 13000 \\
\hline Efficiency[\%] & 80 & 85 & 82 \\
\hline
\end{tabular}

The annual consumption of fragmented wood:

$\mathrm{B}_{\mathrm{dk}}=3600 \times \mathrm{Q} / \mathrm{W}_{\mathrm{d}} \times \eta=3600 \times 50000 / 14000 \times 0,80=16071[\mathrm{~kg}]$

The annual consumption of pellets:

$\mathrm{B}_{\text {pel }}=3600 \times \mathrm{Q} / \mathrm{W}_{\mathrm{d}} \times \eta=3600 \times 50000 / 19000 \times 0,85=11145[\mathrm{~kg}]$

The annual consumption of wood chips:

$\mathrm{B}_{\mathrm{zd}}=3600 \times \mathrm{Q} / \mathrm{W}_{\mathrm{d}} \times \eta=3600 \times 50000 / 13000 \times 0,82=16885[\mathrm{~kg}]$

The annual cost of heating was calculated using the following formula.

where:

$$
\mathrm{K}=\mathrm{B} \times \mathrm{K}_{\mathrm{pal}}[\mathrm{PLN}]
$$

$\mathrm{B}$ - the annual fuel consumption [kg/year], [ $\mathrm{m}^{3} /$ year], $\left[\mathrm{dm}^{3} /\right.$ year $]$

$\mathrm{K}_{\mathrm{pal}}$ - cena paliwa [PLN/unit.]

Biomass prices are shown in the table below.

Table 2. Average Price of biomass [33,34]

\begin{tabular}{|l|l|c|c|}
\hline Fuel Type & \multicolumn{1}{|c|}{$\begin{array}{c}\text { Fragmented } \\
\text { wood }\end{array}$} & Pellet & Wood chips \\
\hline Cost & $330 \mathrm{PLN} / \mathrm{t}$ & $780 \mathrm{PLN} / \mathrm{t}$ & $240 \mathrm{PLN} / \mathrm{t}$ \\
\hline
\end{tabular}

The annual cost of heating with a fragmented wood:

$\left.\mathrm{K}_{\mathrm{dk}}=\mathrm{B} \times \mathrm{K}_{\mathrm{dk}}=16,071 \times 330=5303,43 \mathrm{PLN}\right]$

The annual cost of heating with pellets:

$\mathrm{K}_{\text {pel }}=\mathrm{B} \times \mathrm{K}_{\text {pel }}=11,145 \times 780=8693,10[\mathrm{PLN}]$

The annual cost of heating with wood chips:

$\mathrm{K}_{\mathrm{zd}}=\mathrm{B} \times \mathrm{K}_{\mathrm{zd}}=16,885 \times 240=4052,40[\mathrm{PLN}]$

Coal price: $\mathrm{Kwk}=760 \mathrm{PLN} / \mathrm{t}$

Calorific value: $\mathrm{Wd}=27000 \mathrm{~kJ} / \mathrm{kg}$

The calculation of annual coal consumption:

$\mathrm{BWK}=3600 \times \mathrm{Q} / \mathrm{Wd} \times \eta=3600 \times 50000 / 27000 \times 0.80=8330[\mathrm{~kg} /$ year $]$

The calculation of the annual operating costs for the coal boiler:

$\mathrm{Kwk}=\mathrm{B} \times \mathrm{Kwk}=8.33 \times 760=6330,80[\mathrm{PLN} /$ year $]$

For comparison, the annual cost of heating with coal is very popular 6330,80 [PLN]. 


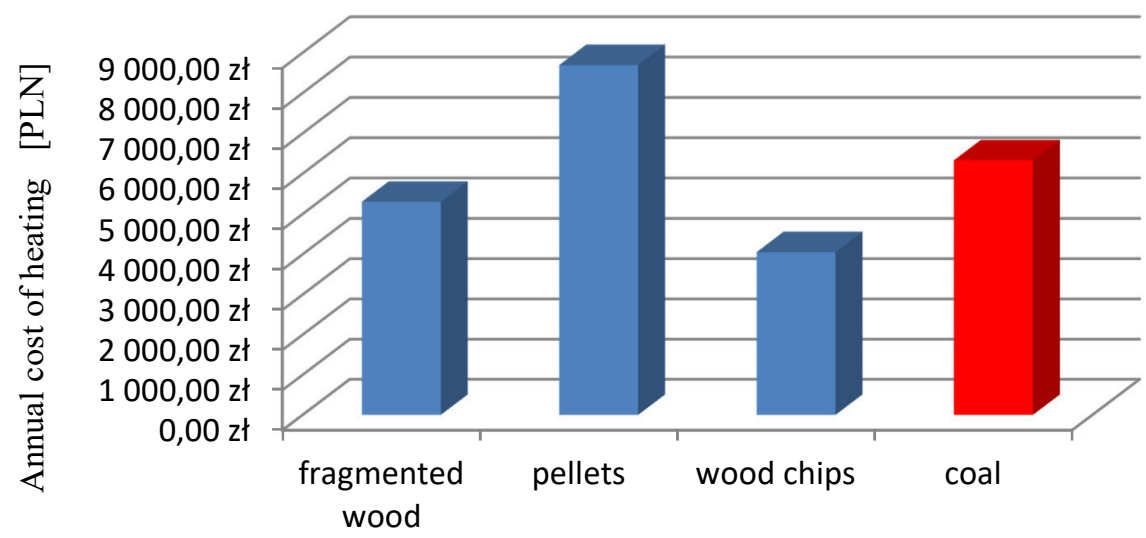

Types of fuels

fragmented wood allets wood chips coal

Fig. 6. Cost of heating

From the performed calculations we can state that the both heating with wood chips and pellet are cheaper than coal. An additional benefit is the low emission accompanying the combustion of biomass.

Another source of energy and at the same time a threat to the environment is landfill gas. The cost of installation use of biogas is approx. US \$ 1 million. However, depending on the quantity and quality (calorific value) of landfill gas, the way of its management and technology as well as market prices of retrieved heat and electricity, the payback time ranges from 2 to 10 years. For an example the village of Malopolska is less than 5.5 years $[5,6]$

From 2013 onwards, each available on the Polish market fuel has a bio additive in the form of biodiesel or bioethanol in the size of $7.1 \%$. In addition, at some stations it is the ability to purchase pure biodiesel that replaces diesel. Its price is a little lower compared with the price of diesel fuel.

\section{Summary}

Analyzing the technical possibilities of biomass utilization in Poland, it is clear that these can cover less than a quarter of the demand for energy. In 2014., Its share accounted for $13.3 \%$ and was comparable with conventional energy sources such as natural gas and electricity. If we compare the energy use of biomass and other renewable sources, it turns out that it represented up to $88 \%$. During the period considered, ie. 2010-2014, one can observe an increase share of liquid biofuels and biogas.

The growing use of biomass mainly results from its low price. Conducted economic analysis showed that both wood chips and fragmented wood is cheaper than the commonly used coal. In addition greatly can reduce emissions associated with a combustion of coal. A similar ecological and economic benefit we can get obtaining energy gas formed in landfills.

Good example of biomass use is being carried out in two municipalities of Malopolska by project From Field to Energy. It is aimed explore potential use of local biomass for NES pellets and pellets from mixed vegetable biomass. It will also determine the impact of the replacement of old boilers for automatic boilers, designed to burn pellets with reduced caloric value to reduce low-emission [35]. 


\section{References}

1. Energia ze źródeł odnawialnych w 2014 r., Informacje i opracowania statystyczne, GUS, Warszawa (2015)

2. Dyrektywa 2001/77/WE z dnia 27 września 2001 r. w sprawie wspierania produkcji na rynku wewnętrznym energii elektrycznej wytwarzanej ze źródeł odnawialnych (2001)

3. Dz. U. Nr 169, poz. 1199, Ustawa z dnia 25 sierpnia 2006 r. o biokomponentach i biopaliwach ciekłych (2006)

4. Dz. U. Nr 34, poz. 182, Rozporządzenie Ministra Gospodarki z dnia 23 lutego 2010 r. zmieniające rozporządzenie w sprawie szczegółowego zakresu obowiązków uzyskania i przedstawienia do umorzenia świadectw pochodzenia, uiszczenia opłaty zastępczej, zakupu energii elektrycznej i ciepła wytworzonych w odnawialnych źródłach energii oraz obowiązku potwierdzania danych dotyczących ilości energii elektrycznej wytworzonej w odnawialnym źródle energii (2010)

5. J. Dudek, P. Klimek, Polityka Energetyczna - Energy Policy Journal 11 (2008)

6. M. Piaskowska-Silarska, Polityka Energetyczna - Energy Policy Journal 16 (2013)

7. L. Borowik, P. Ptak, Przeglad Elektrotechniczny 88 (2012)

8. P. Dulian, B. Garbarz-Glos, W. Bąk, M. Antonova, C. Kajtoch, K. Wieczorek-Ciurowa, H. Noga, Ferroelectrics 497 (2016)

9. B. Garbarz-Glos, W. Bąk, H. Noga, M. Antonova, A. Kalvane, W. Śmiga, Integrated Ferroelectrics 173 (2016)

10. H. Noga, Information technologies and technical education 1 (2009)

11. http://biomasa.org

12. http://energiaodnawialna.net

13. http://stat.gov.pl

14. http://www.zielonaenergia.eco.pl

15. T. Prauzner, Przegląd Elektrotechniczny 88 (2012)

16. W. Sobczyk, K. Sternik, E.J. Sobczyk, H. Noga, Rocznik Ochrona Srodowiska 17 (2015)

17. W. Śmiga, B. Garbarz-Glos, W. Piekarczyk, H. Noga, D. Sitko, M. Karpierz, M. Livinsh, Integrated Ferroelectrics 173 (2016) .

18. I. Turekova, J. Depesova, A. Haskova, T. Bagalova, EDULEARN 15 (2015)

19. W. Hudy, K. Jaracz. K. Pytel, International Carpathian Control Conference 16 (2015)

20. K. Pytel, W. Hudy, H. Noga, W. Kulinowski, International Carpathian Control Conference 17, 401-406, (2016)

21. K. Pytel, W. Hudy, H. Noga, W. Kulinowski, International Carpathian Control Conference 17, 407-412, (2016).

22. K. Pytel, K. Jaracz, S. Gumula, International Carpathian Control Conference 13, 592595, (2012)

23. S. Gumuła, W. Hudy, M. Piaskowska-Silarska, K. Pytel, Przemysl Chemiczny, 94 (2015)

24. K. Pytel, J. Suchanicz, M. Livinsh, A. Sternberg, Phase Transitions, 87 (2014)

25. S. Gumuła, K. Pytel, Mechanics/AGH University of Science and Technology 24(4) (2005)

26. K. Pytel, K. Jaracz, Poznan University of Technology Academic Journals, Electrical Engineering 70 (2012)

27. S. Gumuła, K. Pytel, M. Piaskowska-Silarska, Polish Journal of Environmental Studies, 23, 2315-2320, (2014)

28. S. Gumuła, K. Pytel, M. Piaskowska-Silarska, Polish Journal of Environmental Studies, 23, 2321-2325, (2014) 
29. J. Suchanicz, B. Garbarz-Glos, G. Stopa, T. Kruzina, J. Kusz, M. Zubko, W. Hofmeister, I. Jankowska-Sumara, D. Wcisło, K. Konieczny, R. Rosiek, A. Finder, K. Pytel, M. Dambekalne, A, Sternberg, Integrated Ferroelectrics 108 (2009)

30. J. Suchanicz, G. Stopa, J. Kusz, M. Zubko, W. Hofmeister, M. Antonova, A. Kalvane, M. Dambekalne, A. Sternberg, I. Jankowska-Sumara, B. Garbarz-Glos, D. Wcisło, K. Konieczny, K. Pytel, A. Finder, Journal of Materials Science 45 (2010)

31. K. Pytel, J. Suchanicz, M. Livinsh, A. Sternberg, Condens. Matter Phys., 16 (2013)

32. J. Suchanicz, A. Finder, I. Smeltere, K. Konieczny, I. Jankowska-Sumara, B. GarbarzGlos, M. Sokolowski, R. Bujakiewicz-Korońska, K. Pytel, M. Antonova, A. Sternberg, Integrated Ferroelectrics, 123 (2011)

33. http://www.cenypaliw.eu

34. http://ebiomasa.pl

35. http://ros.edu.pl/images/roczniki/2016/028_ROS_V18_R2016.pdf 